\title{
Rejection of the Cigarette Billboard Sampoerna A Mild "Mula Mula Malu-Malu, Lama Lama Mau"
}

\section{Donna Carollina}

Graduate School of Indonesia Institute of Arts Yogyakarta

\begin{abstract}
In early 2015, a billboard advertisement of cigarette product Sampoerna A Mild titled "Mula Mula Malu-Malu, Lama Lama Mau" or in English means "Initially Feel Shy, Gradually Want" were protested by the majority of Indonesian people. Protests were stated on the website www.change.org, with a petition asking for the billboard to be removed immediately. Shortly after, Sampoerna A Mild company responded to the protest by apologizing to the people of Indonesia and removing the billboard. This case raises several questions for the author: Why was Sampoerna A Mild's billboard removed?; What were the communicative sign contained in the illustrations that causes the billboard to be removed?; What was the idelogical background of Indonesian society which causes them to reject the billboard of Sampoerna A Mild? To answer these questions, this research based on a case study uses the methods of art critic as described by E.B Feldman. Data collection was done based on the study of literature, then the findings were analyzed inductively. Results of research revealed that the billboard was removed because it was considered a pornographic illustration. Pornography as seen in the communicative sign illustration of a young couple hugging each other, as well pornography in the illustration which includes the text that reads "Mula Mula Malu-Malu, Lama Lama Mau" or "Initially Feel Shy, Gradually Want". The majority of Indonesian society rejected the billboard of Sampoerna A Mild and considered the billboard illustration to contain pornography due to their ideological background which is based on ethics and morality of Indonesian culture. Therefore, that rejection of the billboard is mainly due to an illustration displaying things that are in violation of Indonesian culture.
\end{abstract}

Keywords: advertisement, billboard, cigarette product, Sampoerna A Mild, pornography

\section{INTRODUCTION}

Advertising activity continues to change. Changes can be caused by regulations assigned by the government of the country. In Indonesia, the changes can be seen in the advertisement of cigarette products, such as billboards. "Initially Feel Shy, Gradually Want", advertisement of cigarette products can show the form of cigarettes and smoking activity on its advertising illustration. But the practice is no longer done after the Indonesian government certified Undang-Undang Penyiaran 32 Tahun 2002, regulating the practice of promoting the form of cigarettes in their advertisements. As well as the regulations listed in the Etika Pariwara Indonesia, on the discussion about advertising of cigarettes and tobacco products.

The impact of these regulations on the advertisement of tobacco products is the approach that is currently used to communicate the content of the advertisement using communicative signs. It is intended that the consumer or the communicant can read the meaning presented by the communcative signs. But some billboards of tobacco 
products are protested, resisted, and ended with the removal of the advertisement because of the signs that were presented in the illustration billboards, one of which is Sampoerna A Mild's billboard.

In early 2015, a billboard advertisement of cigarette product Sampoerna A Mild titled "Mula Mula Malu-Malu, Lama Lama Mau" or in English means "Initially Feel Shy, Gradually Want" were protested by the majority of Indonesian people. Protests were stated on the website www.change.org, with a petition asking for the billboard to be removed immediately. Shortly after, Sampoerna A Mild company responded to the protest by apologizing to the people of Indonesia and removing the billboard.

The case intrigued the author and raised several questions. Why was Sampoerna A Mild's billboard removed?; What were the communicative signs contained in the illustrations that causes the billboard to be removed?; What was the idelogical background of Indonesian society which causes them to reject the billboard of Sampoerna's A Mild?

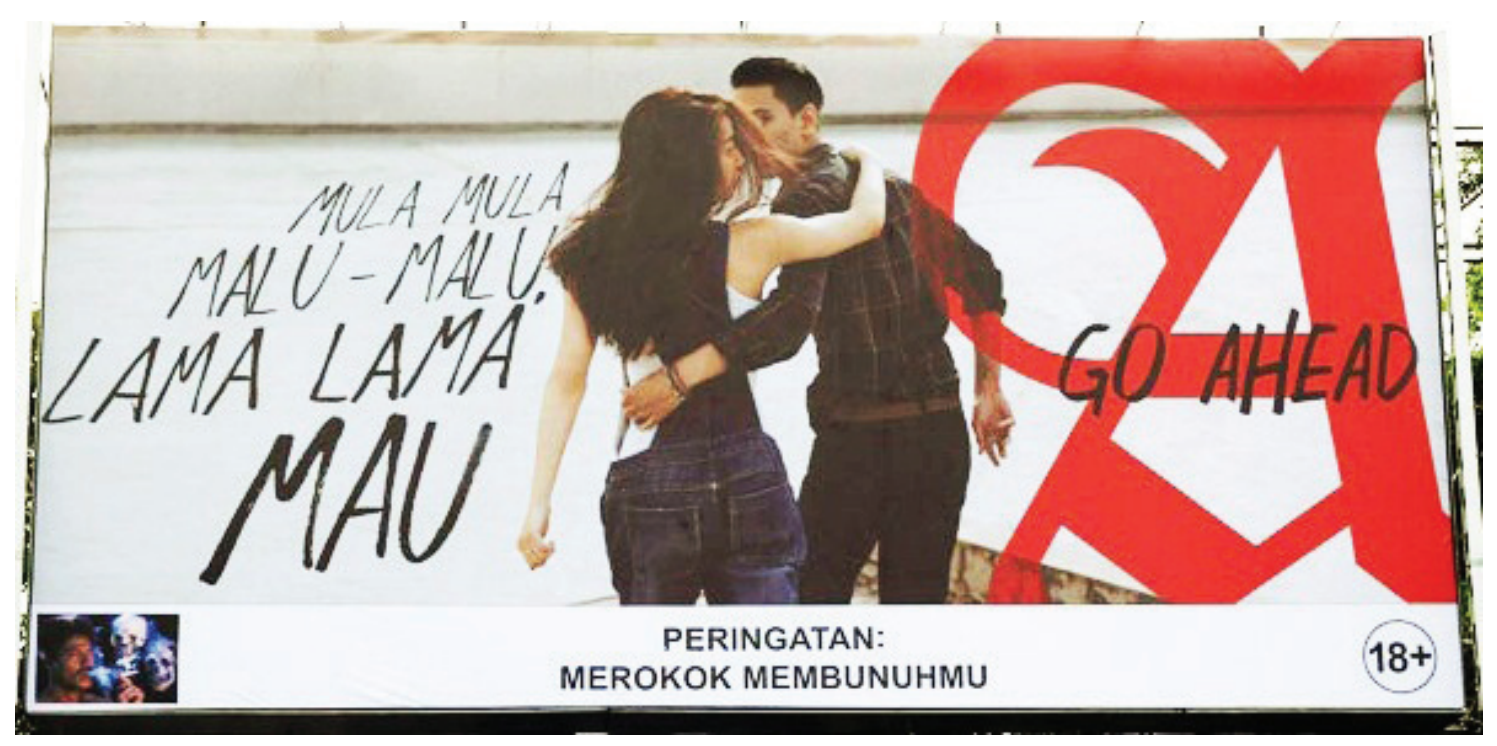

Picture 1. Billboard advertisement of $A$ Mild that received protests from Indonesian society (Accessed from www.habibasyrafy.com, on 18 April 2015).

\section{METHODS}

This research is a qualitative study using a case study approach. To answer the research questions, the methods of art critic as described by E.B Feldman will be used. Feldman (1967:469) described that there are four steps in criticizing the work of art including description, analysis, interpretation, and evaluation.

In the description stage, processes conducted are collecting data of the artworks that are presented directly for the observer. In the description process, the researcher points out on several principle such as: color, direction, shape, the usage of line, texture, volume, and space. On the analysis process, the researcher elaborates the quality of visual elements. Basically, the analysis process examines the quality of the supporting elements of the subject matter, which have been collected within the description of 
the data. Interpretation stage becomes the process conveying the meaning of the artworks, which is gained from the data description and analysis, which are conducted precisely. Leaving from the data description and analysis, the interpretation process is conducted to get a hypothesis about the related artworks. Meanwhile, the last stage that is evaluation process is also known as comparative historical study. This is done with the purpose to conduct comparative study correctly, in order to find out a series of meaning and strength of the artwork expression that are becoming the object of criticism.

Each steps cannot stand individually without the other theories to support and sharpen the research results. It is necessary to use a set of other theories such as visual communication design theory. Theories will be operated on the method of art critic and the data collected by the literature. The findings will then be analyzed inductively.
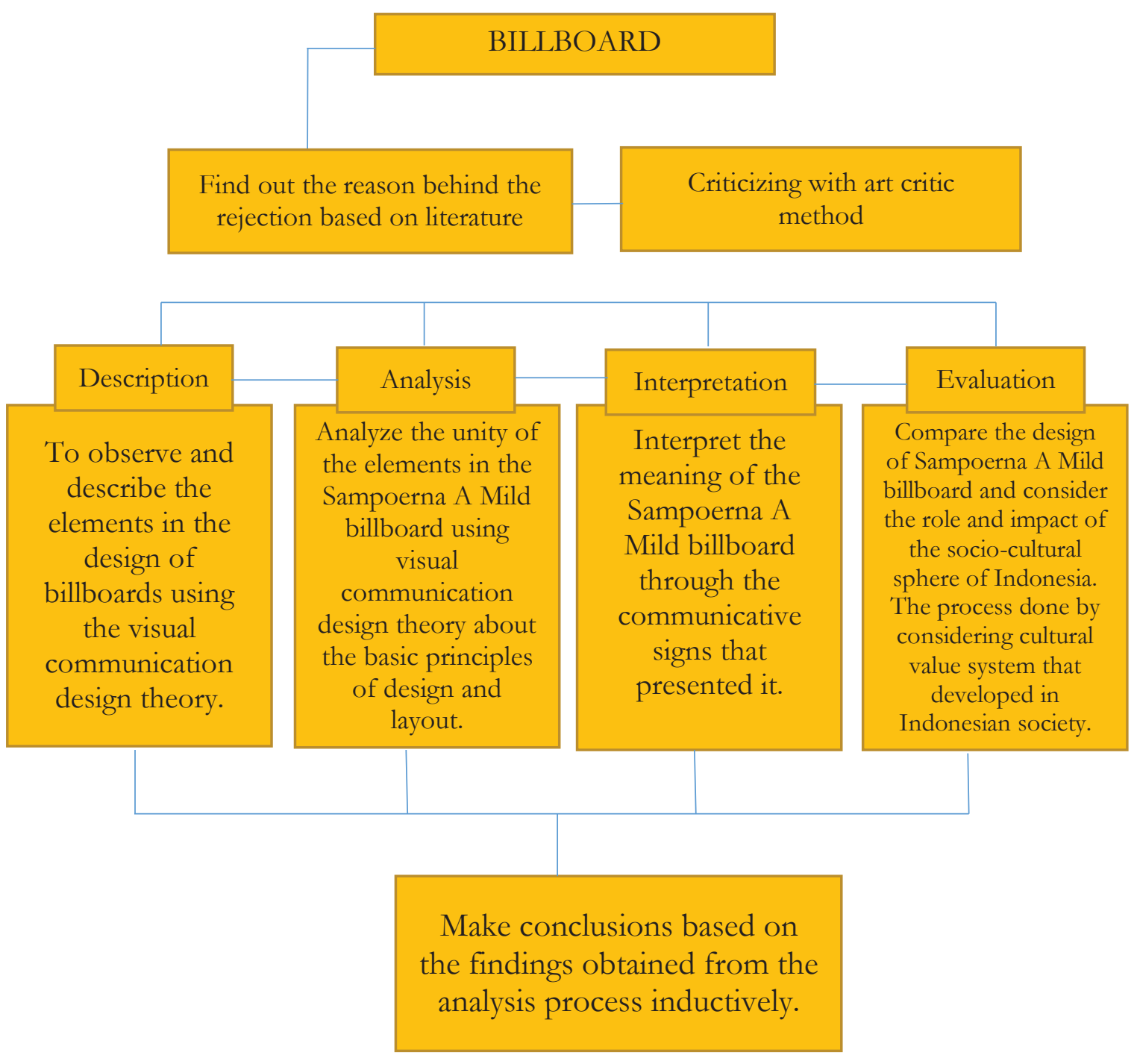


\section{RESULTS}

Sampoerna A Mild is a renowned pioneer of mild cigarette kretek in Indonesia produced since 1989. Sampoerna A Mild's strong dominance in the market of cigarette products in Indonesia is due to the promotion and marketing strategy undertaken, one of which is to advertise on billboards. 1996 was the starting point where Sampoerna A Mild launched an advertising campaign with the power of words and visual illustrations that are able to amaze consumers and communicants. This condition persisted until early 2015, when Sampoerna A Mild's billboard entitled "Mula Mula Malu-Malu, Lama Lama Mau" or in English means "Initially Feel Shy, Gradually Want" was protested by the majority of Indonesian people.

The protests arose because of the assumption that the advertisement production of Bates and Chi agency contains pornography (by Zia Ul Haq in website pksipiyungan. org). Even a protest by Irfan Novianda held as a petition on the website www.change. org, rejected the billboard and asked for public support to have the billboard removed (www.m.tempo.com, on 06 January 2015). Shortly after, Sampoerna A Mild company responded to the protests by apologizing to the people of Indonesia and removing the billboard.

To criticize Sampoerna A Mild's billboard, author uses the method of art critic by E.B Feldman consisting of description, analysis, interpretation, and evaluation. This method is used in order to criticize billboard in detail and depth.

\section{Description}

In description, the billboard used a photo as illustration. This advertisement is a horizontal dimension and have a size of 16:9. Illustration on the billboard have a white background and the illustration shows a young couple hugging each other. In addition to the two young couple image, also appears the text "Mula Mula MaluMalu, Lama Lama Mau" printed in black. Sampoerna A Mild's red logo also appears in the circumstances, distorted but still readable behind the text "Go Ahead" in black. While the bottom of the billboard shows an illustration and text of the smoking ban (regulations required by the Indonesian government). The illustration depicts a male figure holding a cigarette and skull-shaped smoke. Besides the illustration contained the text that reads "Peringatan: Rokok Membunuhmu" or in English means "Warning: Smoking Kills You" in black. While the far right, there is the text " $18+$ " inside the circle and printed in black.

\section{Analysis}

Design is formed by unitary elements. The elements includes illustrations, photography, symbols, and typography (Adityawan, 1999: 3). In the outline, the key elements in the illustration of Sampoerna's billboard includes photography and typography, where the photo shows a young couple hugging each others and the typography reads "Mula Mula Malu-Malu, Lama Lama Mau" and also "Go Ahead". The placement of each elements in the layout are united and balanced. This balance are seen from the arrangement of elements that makes up the illustration. Layout uses 
symmetrical balance, with one column grid (grid manuscript). It is seen from the balance on each side of the layout (Anggraini \& Nathalia, 2014: 63). The typeface used for the text is decorative, where this type is usually used only for the title (heading) text (Anggraini \& Nathalia, 2014: 63). In relation with the use of typography, the illustration billboard of Sampoerna has fulfilled the criteria, good legibility and readibilty.

\section{Interpretation}

In Sampoerna A Mild's billboard, elements that stands out and is the main point lies on the photo depicting a young couple hugging each other and the text "Mula Mula Malu-Malu, Lama Lama Mau". Both of these objects becomes the system referents for the deciphering of meaning. This is possible because the advertisement, though its function is to sell the objects, also shows the process of meaning (Williamson, 2007:2).

Broadly speaking, the photograph was appointed based on the image of selfexpression of Indonesian teenagers today. Especially with the style of dress in casual outfit, which is synonymous with freedom of expression for teenagers. This is reinforced by the tattoo on the boy's arm. Most people argue that tattoos are a form of self-expression. Similarly, the girl with loose hair and sleeveless shirts that shows their whole arms also reinforced the statement. Loose hair and bare arms showing sensuality of women, as is often exposed by the mass media, had become the typical stereotypes of beauty and sensuality of modern women.

This illustration depicts how the reality of the freedom of young people to behave and get along today, unabashedly showing the close relationship between the opposite sexes. As depicted on the object, the young couple is hugging each other, but there is still a distance between each of their bodies. As if they have a close relationship but there is still a distance. It is also seen from the position of the girl who is looking away from the face of the boy.

The text "Mula Mula Malu-Malu, Lama Lama Mau" clarifies the photo illustration, explaining that the relationship between the couple is relatively new. There is a hesitation, represented by the word "Malu-Malu" or in English means "Shy". "Mula Mula Malu-Malu" or in English "Initially Feel Shy, Gradually Want" indicates that at the beginning of every relationship, they seem "Malu-Malu" or in English "Shy" between each other. In the photo, the object described as the "Mula Mula Malu-Malu" geared more towards the girl. Because the girl is in the arms of the boy, from this position it was assumed that the boy in the photo is trying to "lead" the girl, who look embarassed.

Furthermore, the text "Lama Lama Mau" or in English "Then Wanting" tries to convince the communicant that although "Initially Feel Shy, Gradually Want", the girl at the first time will feel shy but gradually will "Mau" or in English "Want". The word "Mau" can be translated into a fairly broad range of meanings. However, the orientation of this word directed to negative associations. These words seems to be aimed to the context of the freedom in their relationship. "Mau" can be interpret as to do more things in their relationship. This assumption can easily arise because today's 
youth with the identity of freedom of expression, is considered closely lapsed into a free sex activity. These negative associations tends to be harassing or demeaning girls. In additiion, the phrase "Go Ahead" can be interpeted in Indonesian "silahkan saja" or "go ahead, there is no problem with it". The tagline used as approving or undestanding that smokers are free to do anyhing they wanted with no need for doubt. The text "Mula Mula Malu-Malu, Lama Lama Mau" have another alternative interpretation for new smokers who are "Initially Feel Shy, Gradually Want" shy to smoke. New smokers (mostly young smokers) often hides the fact that they smoked. Thus, these smokers often smokes secretly. But over time, these smokers got used to it and are no longer ashamed to smoke even in public.

\section{Evaluation}

A Mild is firstly launched in 1989. A Mild cigarette is popular with its slogan or tagline that are always presented in its commercial advertisement. Those slogan or tagline often trigger communicants and consumers who notice it. Consumer can easily remember each slogan or tagline of the A Mild products because the sentences are unique and supported with interesting advertisement illustration. A Mild seems to be so smart by using marketing strategy not only offering functional value (which is commonly used by the majority of advertisement) but also emotional value. Those emotional value cover creativity, smartness, and becoming the trendsetter among other law tar cigarette products.

A Mild use the tagline firstly in 1995 saying that "Bukan Basa Basi" which means "Not a Courtessy". In the year of 2002 until 2004 they continued to make commercial champagne with the theme "Others Can Only Follow". Then in 2005 A Mild commercial champagne changed the tagline theme into "Tanya Kenapa" meaning "Ask Why" which was considered as a touching one because it carried several social issues. Afterwards, in the year of 2009 until this time, the tagline which is issued is "Go Ahead" in which the commercial ads with the tagline "Mula Mula Malu-Malu, Lama Lama Mau" meaning that "Initially Feel Shy, Gradually Want" belongs to that.

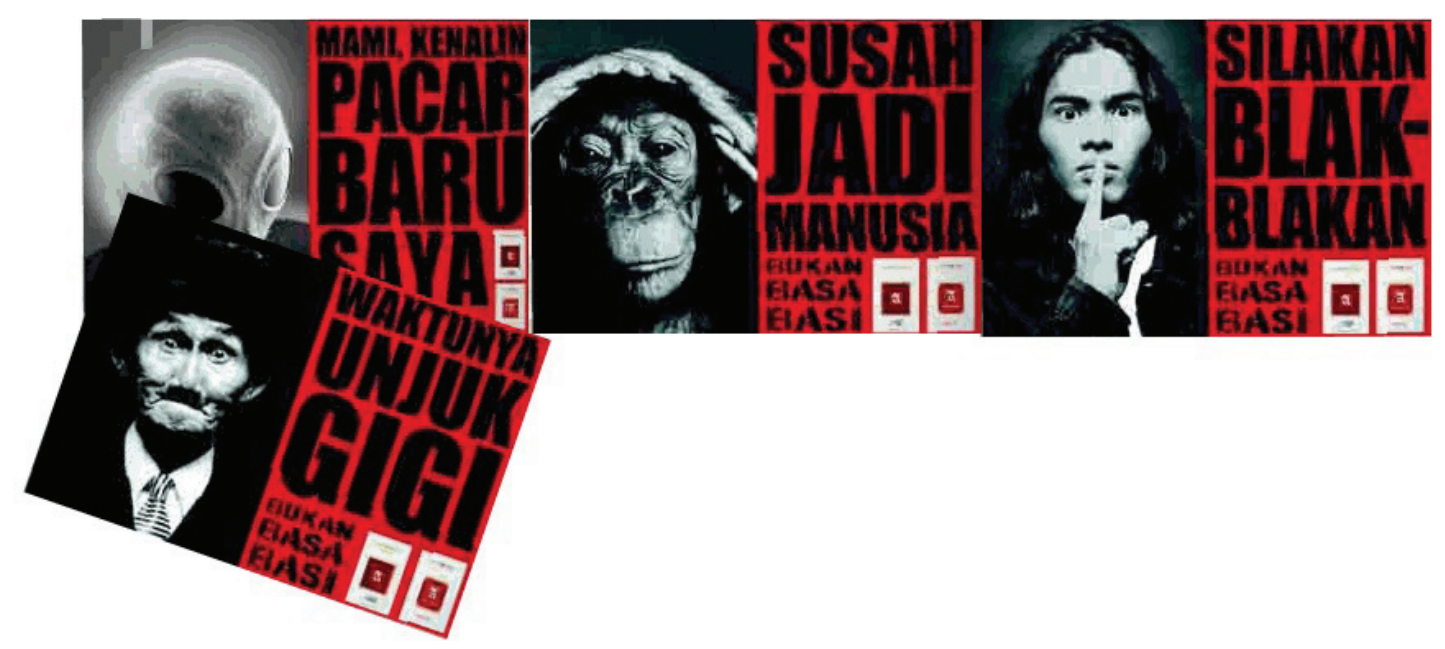

Picture 2. A Mild ads in year 1995 "Bukan Basa Basi". http://photos1.blogger.com/ blogger/3761/3108/1600/2.gif\&imgrefurl=http://selembarkertas.blogspot.com/2006/07/marketingdakwah-part-1.html, on May 25, 2015. 
Donna Carollina, Rejection of the Cigarette Billboard...

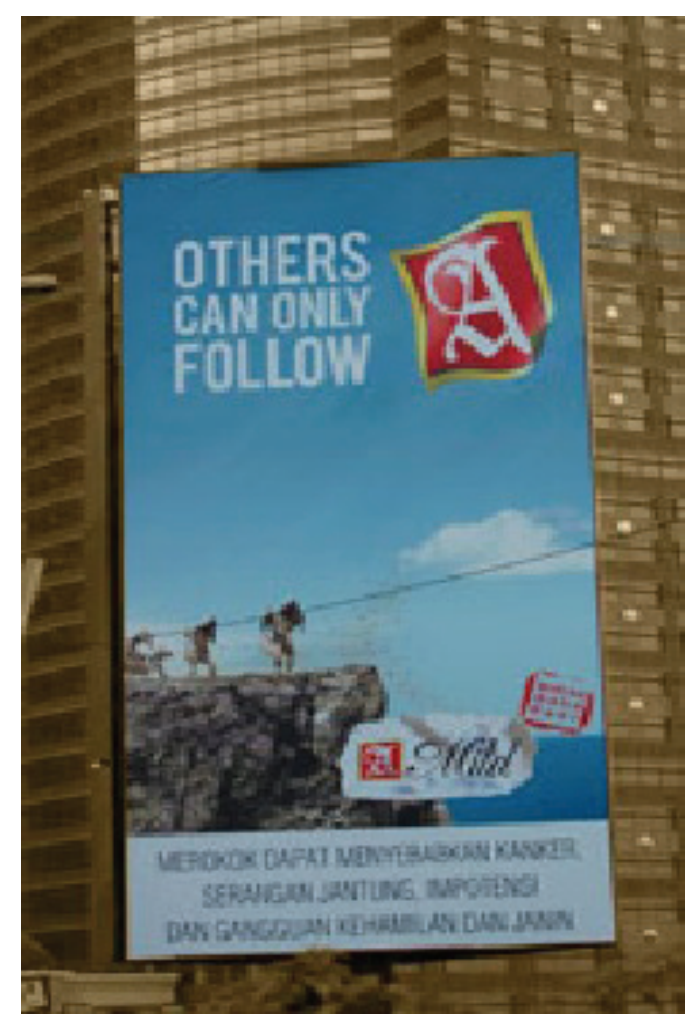

Picture 3. A Mild ads in year 2002 "Others Can Only Follow". https://safrony.wordpress. com/2011/03/22/di-balik-slogan-indah-iklan-rokok, on May 25, 2015.

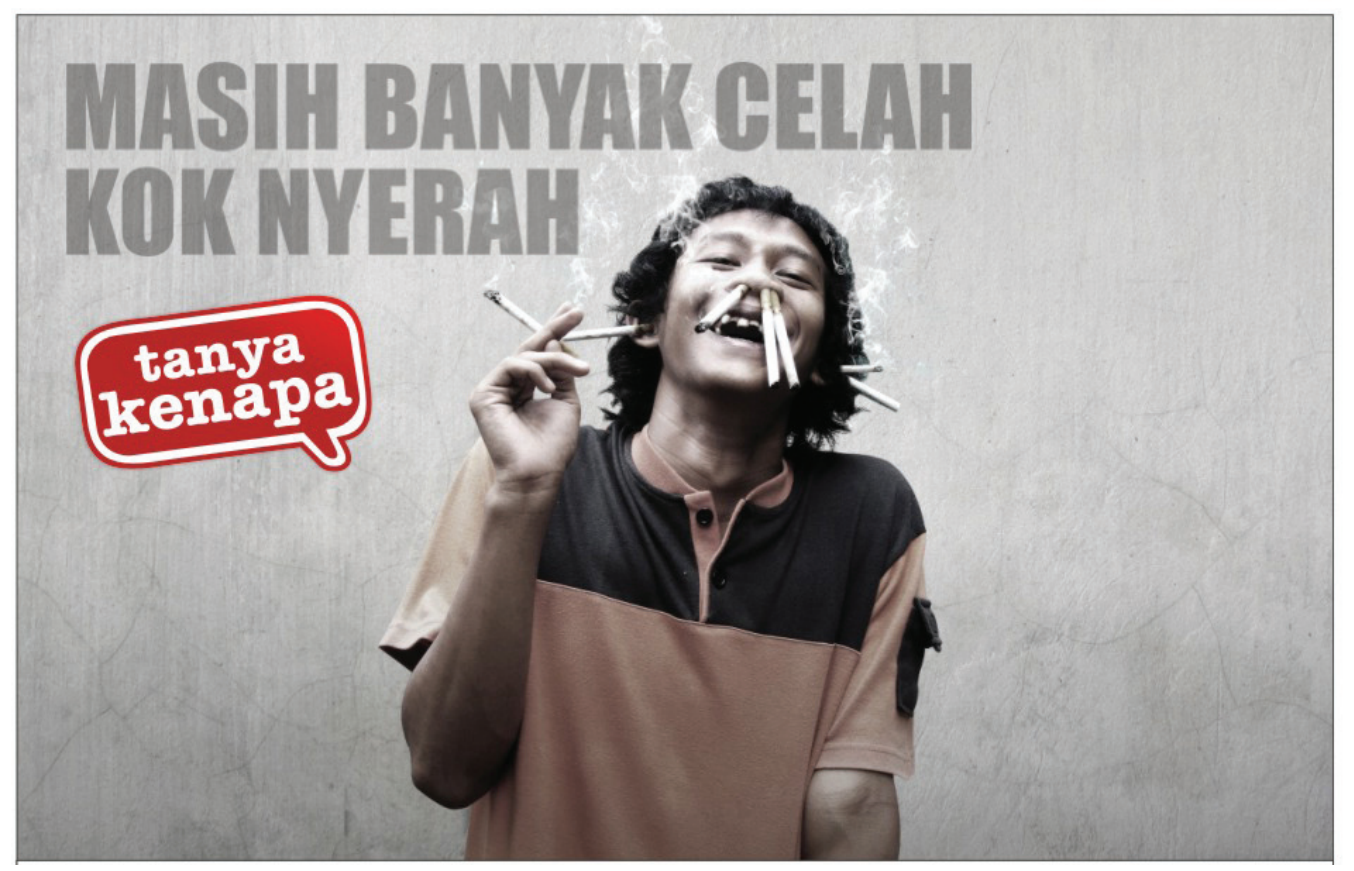

Picture 4. A Mild ads in year 2005 "Tanya Kenapa" dalam iklan "Masih Banyak Celah Kok Nyerah". https://safrony.wordpress.com/2011/03/22/di-balik-slogan-indah-iklan-rokok, on May 25, 2015.

Generally the theme of Sampoerna A Mild's advertising campaigns from 1996 to 2015 often raised social issues that are rife in Indonesia. The theme was appointed in its advertising tagline to provoke and reflect the social atmosphere within the Indonesian community. Because of the actuality of the theme raised, few consumers and communicants are interested in Sampoerna A Mild. 
Likewise with the theme "Go Ahead" which started in 2009. This tagline is used as a encouragement for smokers of Sampoerna A Mild to do what they like without hesitation. But this time, the theme was quite provocative as Sampoerna A Mild tried to give a picture of the reality of young people today in their daily run.

The creative process in designing the commercial ads theme along with the illustration as the promotional media comes to the crisis by the release of the government regulation. The regulation makes a restriction of the cigarette promotional media by forbidding presenting an image of a figure who is smoking or the real image of cigarettes itself. Because of that government regulation, A Mild put effort on enhancing the creative process of the advertisement. The creative process is conducted by managing the use of sign that are able to present values that are implicity carried within the products. However, they still keep the marketing system that brings emotional values that are often used put priority on the self-actualization, selffreedom, self-identity, the life that is chosen, creativity, and also other uniqueness within an individual in which having a majority as the Indonesian youth.

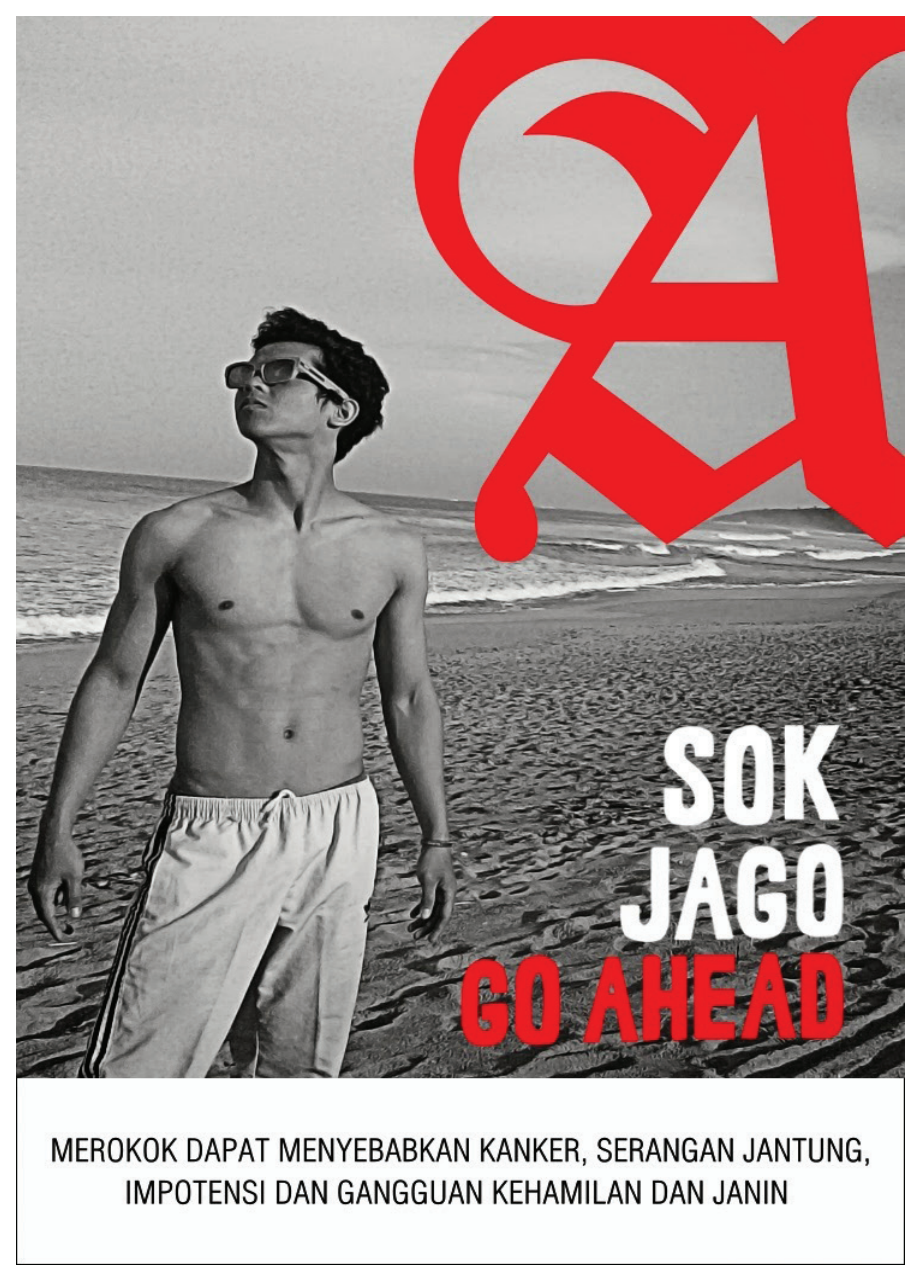

Picture 5. A Mild “Go Ahead” version “Sok Jago". http://abdulobam.blogspot.com/2015/01/kumpulantemplate-iklan-rokok.html, on May 25, 2015. 
Donna Carollina, Rejection of the Cigarette Billboard...

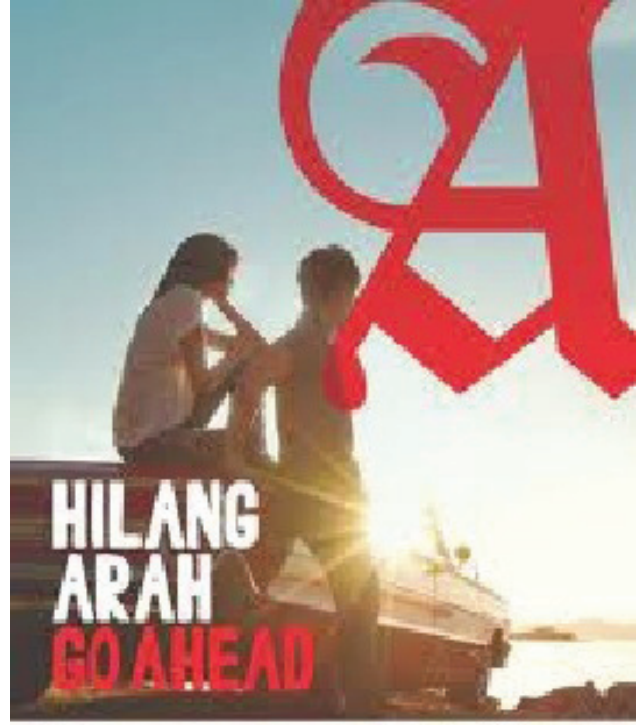

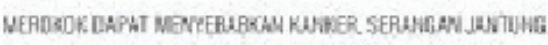

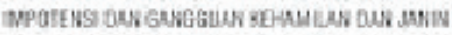

Picture 6. A Mild "Go Ahead" version "Hilang Arah". http://www.habibasyrafy.com/2013/06/iklan-provokatifgo-ahead.html, on May 25, 2015.

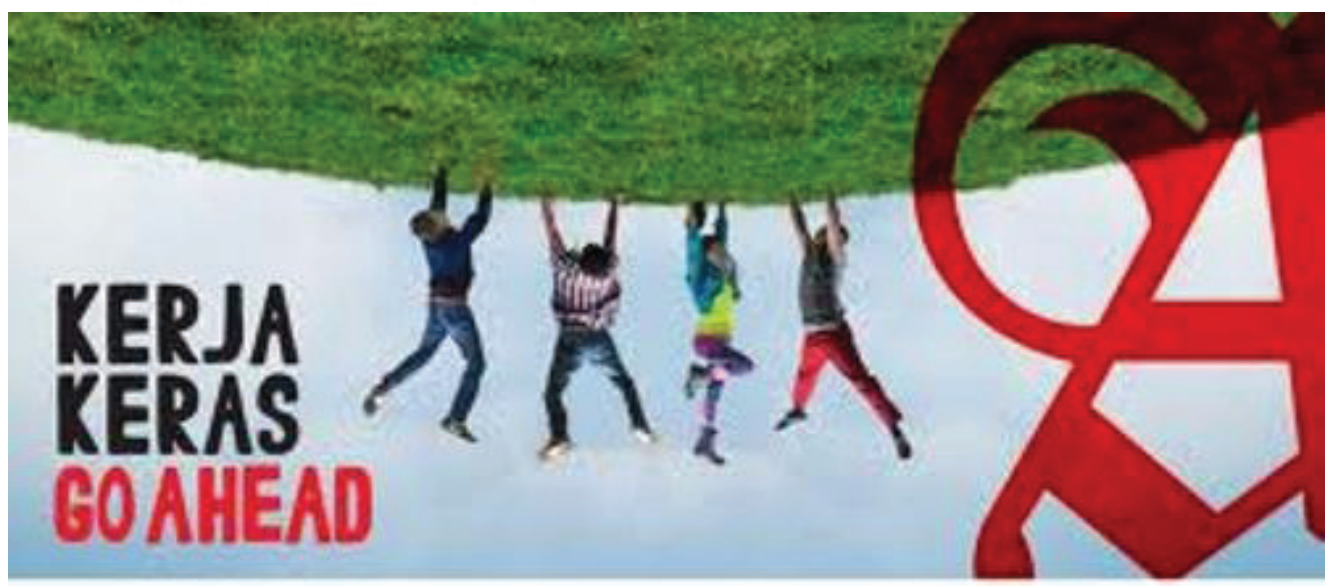

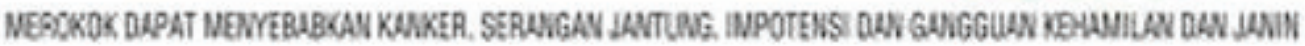

Picture 7. A Mild "Go Ahead" version "Kerja Keras". www.habibasyrafy.com\%2F2013\%2F06\%2Fiklanprovokatif-go-ahead.html, on May 25, 2015.

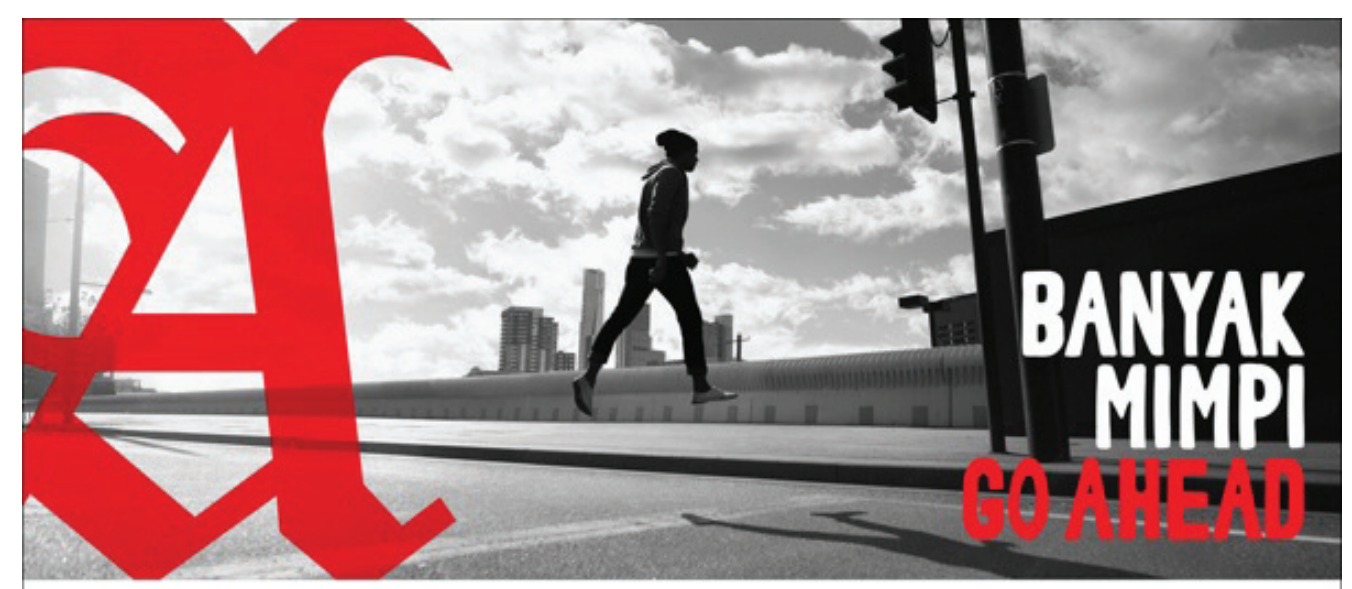

MEROKOK DAPAT MENYEBABKAN KANKER, SERANGAN JANTUNG, IMPOTENSI DAN GANGGUAN KEHAMILAN DAN JANIN

Picture 8. A Mild "Go Ahead" version "Banyak Mimpi". http://lasvegascasinoplayersclub.com/iklan-umild-ngantor/, on May 25, 2015. 
"Mula Mula Malu-Malu, Lama Lama Mau" billboard included in the advertising campaign carries the theme "Go Ahead". This billboard was protested by the assumption that the illustration of the billboard contains pornography. "Mula Mula Malu-Malu, Lama Lama Mau" and the text "Go Ahead" reinforced the assumptions that it tolerates the action of free sex. Combination of this text can be read as "Initially Feel Shy, Gradually Want" it was shy but later will wanting, its okay and go ahead". Although there are alternatives to interpret the meaning of these billboards that relates to new smokers, who are "Initially Feel Shy, Gradually Want", shy to smoke then no longer as doubtful, the illustration of a young couple hugging each other reinforced a meaning that implies pornography. This interpretation then brought on the removal of the Sampoerna A Mild's billboard.

In relation to pornography, it refers to the definition of writing, pictures, or objects that violate decency, or text, images, or objects that can evoke or stimulate lust (KBBIIndonesian Dictionary). The things related to pornography has been regulated in $U U$ RI No. 44 Tahun 2008 and Etika Pariwara Indonesia Poin 1.26 related to pornography. From the description of these articles, the illustration of Sampoerna A Mild's billboard fit into a category that contains pornographic material. It is seen from the photos and text that linked to pornography. The illustrations are exploiting things that violate cultural values of Indonesian society.

Cultural values consisting of concepts concerning all things are considered valuable and important to a society. This value is used to guide the life of the community. Cultural values are the highest and most abstract level of customs (Koentjaraningrat, 2014:75-76). Customs serves as guidelines for the Indonesian community, living in accordance with those disclosed in the proverb "Adat bersendi syarak, syarak bersendi kitabullah", meaning in acting, human must always remember the rules of custom and religion. And in another proverb, it says, "Adat di isi, lembang dituang", meaning doing everything according to the custom (Chaniago, 1993:14). These proverbs are deeply trusted by most of Indonesian people.

Indonesian people tends to believe the motto and symbols made by themselves (Lubis, 2013:29). Then it creates the Indonesian society whose cultural characters are elegant, gentle (sentimental), spiritual, noble, and civilized. The society is very concerned with the cultural values of ethic (noble and spiritual) and morality (civilized). It makes pornography as a thing that violates the rules of ethic and do not reflect the morality of Indonesian society. Thus, Sampoerna A Mild's billboard was rejected by most of Indonesian society because the illustrations contained in the billboard does not reflect the ideology of Indonesian culture. 


\section{BIBLIOGRAPHY}

Adityawan S, Arief. 1999, Tinjauan Desain: Dari Revolusi Industri Hingga Posmoderen. Cetakan ke-1. Jakarta: UPT Penerbitan Universitas Tarumanegara.

Chaniago, Amran. 1993, 1700 Peribahasa Indonesia. Bandung: PustakaSetia.

Dewan Periklanan Indonesia. 2007, Etika Pariwara Indonesia: Tata Krama Dan Tata Cara Periklanan Indonesia. Cetakan ketiga . Jakarta: Dewan Periklanan Indonesia.

Feldman, Edmund Burke. 1967, Art as Image and Idea. New Jersey: Prentice Hall, Inc.

Koentjaraningrat. 2014, Pengantar Antropologi I. Cetakan keempat. Jakarta: Rineka Cipta.

Lubis, Mochtar. 2013, Manusia Indonesia. Jakarta: Yayasan Pustaka Obor Indonesia.

Martanto, Syahrial Wiryawan \& Wahyu Wagiman. 2007, Tindak Pidana Pornografi dan Pornoaksi Dalam RUU KUHP. Jakarta: ELSAM dan Aliansi Nasional Reformasi KUHP.

Williamson, Judith. 2007, Decoding Advertisement: Membedah Ideologi dan Makna Dalam Periklanan.Yogyakarta: Jalasutra.

https://www.pkspiyungan.org/2015/01/kenapa-iklan-rokok-lebih-kreatif-tanpa.html. April 18, 2015.

https://www.change.org/p/sampoerna-akhirnya-hentikan-reklame-mesum-iklanrokok-a-mild. April 18, 2015.

https://m.tempo.co/read/news/2015/01/06/078633182/Ini-Penggagas-Petisi-Tolak-IklanRokok-Mesum. Mei 5, 2015.

http://photos1.blogger.com/blogger/3761/3108/1600/2.gif\&imgrefurl=http:// selembarkertas.blogspot.com/2006/07/marketing-dakwah-part-1.html. May 25, 2015.

https://safrony.wordpress.com/2011/03/22/di-balik-slogan-indah-iklan-rokok. May 25, 2015.

http://abdulobam.blogspot.com/2015/01/kumpulan-template-iklan-rokok.html. May 25, 2015.

http://www.habibasyrafy.com/2013/06/iklan-provokatif-go-ahead.html. May 25, 2015. http://lasvegascasinoplayersclub.com/iklan-u-mild-ngantor/. May 25, 2015. 